\title{
Balnearium lithotrophicum gen. nov., sp. nov., a novel thermophilic, strictly anaerobic, hydrogen- oxidizing chemolithoautotroph isolated from a black smoker chimney in the Suiyo Seamount hydrothermal system
}

Correspondence
Ken Takai
kent@jamstec.go.jp

\author{
Ken Takai, ${ }^{1}$ Satoshi Nakagawa, ${ }^{2}$ Yoshihiko Sako ${ }^{2}$ and Koki Horikoshi ${ }^{1}$ \\ 'Subground Animalcule Retrieval (SUGAR) Project, Japan Marine Science and Technology \\ Center, 2-15 Natsushima-cho, Yokosuka 237-0061, Japan \\ ${ }^{2}$ Laboratory of Marine Microbiology, Division of Applied Biosciences, Graduate School of \\ Agriculture, Kyoto University, Oiwake-cho, Kitashirakawa Kyoto 606-8502, Japan
}

\begin{abstract}
A novel, extremely thermophilic bacterium, designated strain $17 S^{\top}$, was isolated from a deep-sea hydrothermal vent chimney at the Suiyo Seamount in the Izu-Bonin Arc, Japan. The cells were rods with no apparent motility, most of which were narrow in the middle in the exponential-growth phase and had several polar flagella at both ends. Growth was observed between 45 and $80^{\circ} \mathrm{C}$ (optimum temperature, $70-75^{\circ} \mathrm{C}$; doubling time, $80 \mathrm{~min}$ ) and between $\mathrm{pH} 5.0$ and $7 \cdot 0$ (optimum $\mathrm{pH}, 5 \cdot 4$ ). The isolate was a strictly anaerobic chemolithoautotroph that was capable of using molecular hydrogen as its sole energy source and carbon dioxide as its sole carbon source. Elemental sulfur $\left(\mathrm{S}^{0}\right)$ was required for growth as an electron acceptor. The $\mathrm{G}+\mathrm{C}$ content of the genomic DNA was 34.6 mol\%. Phylogenetic analysis based on $16 \mathrm{~S}$ rDNA sequences indicated that the isolate was related to Thermovibrio ruber ED11/3LLK ${ }^{\top}$ and Desulfurobacterium thermolithotrophum $\mathrm{BSA}^{\top}$, whilst it appeared to be a novel lineage prior to the divergence of these genera. This isolate could also be differentiated from both $T$. ruber ED11/3LLK ${ }^{\top}$ and $D$. thermolithotrophum $\mathrm{BSA}^{\top}$ on the basis of physiological properties. The name Balnearium lithotrophicum gen. nov., sp. nov. is proposed for this isolate (type strain, $17 \mathrm{~S}^{\top}=\mathrm{JCM}$

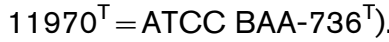

Molecular hydrogen is one of the most abundant gas components of deep-sea hydrothermal emission [together with carbon dioxide, hydrogen sulfide and methane (Von Damm, 1995; Shanks, 2001)] and may serve as a primary energy source for microbial communities in deep-sea hydrothermal systems. A number of hydrogen-oxidizing, chemolithoautotrophic, thermophilic genera have been obtained from a variety of deep-sea hydrothermal systems: the archaeal genera Pyrolobus (Blöchl et al., 1997), Pyrodictium (Pley et al., 1991), Ignicoccus (Huber et al., 2000), Geoglobus (Kashefi et al., 2002), Archaeoglobus (Burggraf et al., 1990;

Published online ahead of print on 23 May 2003 as DOI 10.1099/ ijs.0.02773-0.

Abbreviations: FAME, fatty acid methyl ester; MAR, Mid-Atlantic Ridge. The GenBank/EMBL/DDBJ accession number for the $16 \mathrm{~S}$ rDNA sequence of strain $17 S^{\top}$ is $A B 105048$.

Growth curves showing the effects of temperature, $\mathrm{pH}$ and $\mathrm{NaCl}$ concentration on the growth of Balnearium lithotrophicum $17 S^{\top}$ are available as supplementary material in IJSEM Online.
Huber et al., 1997), Methanopyrus (Huber et al., 1989; Kurr et al., 1991), Methanocaldococcus (Zhao et al., 1988; Jeanthon et al., 1998, 1999a; Jones et al., 1983, 1989), Methanotorris (Jeanthon et al., 1999b) and Methanothermococcus (Takai et al., 2002) and the bacterial genera Desulfurobacterium (L'Haridon et al., 1998), Aquifex (Van Dover et al., 2001; Takai et al., 2003c), Persephonella (Reysenbach et al., 2000; Götz et al., 2002; Nakagawa et al., 2003), Nautilia (Miroshnichenko et al., 2002) and Caminibacter (Alain et al., 2002) are listed. Despite the diversity of archaeal members, hydrogen-oxidizing, chemolithoautotrophic, thermophilic Bacteria are limited to members of the phylum Aquificae or $\varepsilon$-subclass of the Proteobacteria. Although deep-sea hydrothermal vent Aquifex and Persephonella strains are facultative anaerobes that are capable of growth by using elemental sulfur or nitrate as electron acceptors (Reysenbach et al., 2000; Götz et al., 2002; Nakagawa et al., 2003; Takai et al., 2003c), members of the genera Desulfurobacterium, Nautilia and Caminibacter are strictly anaerobic hydrogen-oxidizers (L'Haridon et al., 1998; Alain et al., 2002; Miroshnichenko et al., 2002). 
Desulfurobacterium thermolithotrophum $\mathrm{BSA}^{\mathrm{T}}$ is a strictly anaerobic, hydrogen-oxidizing, sulfur- or thiosulfatereducing chemolithoautotroph that was isolated from a deep-sea hydrothermal vent chimney at the Mid-Atlantic Ridge (MAR) (L'Haridon et al., 1998). It has a higher temperature range for growth than $\varepsilon$-proteobacterial genera from deep-sea hydrothermal environments (L'Haridon et al., 1998; Alain et al., 2002; Miroshnichenko et al., 2002); hence, members of the genus Desulfurobacterium are likely to play an important role in microbial ecosystems that occur in higher temperatures of habitats close to hydrothermal emission. To date, only one species in this genus, D. thermolithotrophum $\mathrm{BSA}^{\mathrm{T}}$, has been reported from deep-sea hydrothermal environments (L'Haridon et al., 1998) and a phylogenetically related entity, Thermovibrio ruber $\mathrm{ED} 11 / 3 \mathrm{LLK}^{\mathrm{T}}$, has been obtained from coastal marine hydrothermal water and sediments (Huber et al., 2002). T. ruber ED $11 / 3 \mathrm{LLK}^{\mathrm{T}}$ is also a strictly anaerobic, hydrogenoxidizing chemolithoautotroph that uses sulfur or nitrate as electron acceptors (Huber et al., 2002). These genera might comprise a novel lineage within the phylum Aquificae, distantly related to the families Aquificaceae and 'Hydrothermaceae' (Eder \& Huber, 2002); their phylogenetic and physiological diversities are still uncertain.

Throughout microbiological expedition in the Suiyo Seamount deep-sea hydrothermal system in the Izu-Bonin Arc, Japan (Takai \& Horikoshi, 1999; Nakagawa et al., 2003; Sako et al., 2003; Takai et al., 2003a), we have sought to cultivate strictly anaerobic, hydrogen-oxidizing, chemolithoautotrophic thermophiles from black smoker chimney structures. This study has aimed to characterize the primary producer of the microbial ecosystem in hot, anoxic habitats in the chimney structure. Cultivation of thermophilic methanogens, and even detection of their rDNA sequences by using culture-independent, molecular techniques, have so far been unsuccessful (Takai \& Horikoshi, 1999; Nakagawa et al., 2003; Sako et al., 2003; Takai et al., 2003a). Alternatively, a strictly anaerobic, thermophilic chemolithoautotroph was isolated from a black smoker chimney sample in the Suiyo Seamount deep-sea hydrothermal system by using media enriched with hydrogen and elemental sulfur. Here, characterization of this new isolate is reported.

\section{Sample collection, enrichment and purification}

Sample collection and subsampling procedures are described elsewhere (Nakagawa et al., 2003; Sako et al., 2003; Takai et al., 2003a). A portion (approx. $10 \mathrm{~g}$ ) of the subsample obtained from the chimney surface was suspended with $20 \mathrm{ml}$ sterilized MJ synthetic sea water (Sako et al., 1996) that contained $0.05 \%(\mathrm{w} / \mathrm{v})$ sodium sulfide in a $100 \mathrm{ml}$ glass bottle (Schott Glaswerke) sealed tightly with a butyl rubber cap under an $\mathrm{N}_{2}$ atmosphere. The suspended slurry was used to inoculate a series of media, including MJAIS medium (described below), under a gas phase of $80 \% \mathrm{H}_{2}$ and $20 \% \mathrm{CO}_{2}(300 \mathrm{kPa})$; the cultures were incubated at $70{ }^{\circ} \mathrm{C}$ in a dry oven on board.
Growth of anaerobic thermophiles was observed in MJAIS medium after 2 days incubation at $70^{\circ} \mathrm{C}$. Enrichment cultures at $70^{\circ} \mathrm{C}$ contained mostly rod-shaped cells that were narrow in the middle. A pure culture was obtained by using the dilution-to-extinction technique at $70{ }^{\circ} \mathrm{C}$ with the same medium that was used for enrichment (Takai \& Horikoshi, 2000). The culture in the tube that showed growth at the highest dilution was designated strain $17 \mathrm{~S}^{\mathrm{T}}$ $\left(=\mathrm{JCM} 11970^{\mathrm{T}}=\right.$ ATCC BAA-736 $\left.{ }^{\mathrm{T}}\right)$. Purity was confirmed routinely by microscopic examination and by repeated partial sequencing of the $16 \mathrm{~S}$ rRNA gene with several PCR primers.

\section{Morphology}

Cells were observed routinely under an Olympus phasecontrast BX51 microscope with the SPOT RT Slider CCD camera system (Diagnostic Instruments). For microscopy at $70{ }^{\circ} \mathrm{C}$, a drop of culture at $70{ }^{\circ} \mathrm{C}$ was placed on a slide preheated to $75^{\circ} \mathrm{C}$ and observed immediately. Transmission electron microscopy of negatively stained cells and thin sections of the cells was carried out as described by Zillig et al. (1990) and Takai et al. (1999). Cells grown in MJAIS medium at $70{ }^{\circ} \mathrm{C}$ in the mid-exponential growth phase were fixed by adding formaldehyde at a final concentration of $4.0 \%(\mathrm{w} / \mathrm{v})$ to the culture for $30 \mathrm{~min}$ at $70{ }^{\circ} \mathrm{C}$; cells were then subjected to electron microscopic observation. Cells of strain $17 \mathrm{~S}^{\mathrm{T}}$ were Gram-negative rods that were about $0 \cdot 7-0 \cdot 9 \mu \mathrm{m}$ in width and $2 \cdot 5-3 \cdot 5 \mu \mathrm{m}$ in length; most cells in the exponential-growth phase were narrow in the middle $(0 \cdot 5-0 \cdot 7 \mu \mathrm{m}$ in width) (Fig. $1 \mathrm{a}$ and b). Motility was not evident in laboratory cultures, although several polar flagella were observed at both ends of the cell (Fig. 1a). Electron microscopic observation indicated that cells divided at the narrow part in the middle. These morphological features were quite different from those of T. ruber ED11/3LLK ${ }^{\mathrm{T}}$ (Huber et al., 2002) and D. thermolithotrophum $\mathrm{BSA}^{\mathrm{T}}$ (L'Haridon et al., 1998) (Table 1).

\section{Growth characteristics}

Strain $17 \mathrm{~S}^{\mathrm{T}}$ was cultivated routinely in MJAIS medium, which consisted of $30 \mathrm{~g} \mathrm{NaCl}, 0.09 \mathrm{~g} \mathrm{~K}_{2} \mathrm{HPO}_{4}, 0.07 \mathrm{~g}$ $\mathrm{KH}_{2} \mathrm{PO}_{4}, 0 \cdot 8 \mathrm{~g} \mathrm{CaCl}_{2}, 3 \cdot 4 \mathrm{~g} \mathrm{MgSO}_{4} \cdot 7 \mathrm{H}_{2} \mathrm{O}, 4 \cdot 18 \mathrm{~g} \mathrm{MgCl}_{2} \cdot 6 \mathrm{H}_{2} \mathrm{O}$, $0.33 \mathrm{~g} \mathrm{KCl}, 10 \mathrm{mg} \mathrm{NiCl} 2.6 \mathrm{H}_{2} \mathrm{O}, 10 \mathrm{mg} \mathrm{Na} \mathrm{SeO}_{3} .5 \mathrm{H}_{2} \mathrm{O}$, $10 \mathrm{mg} \mathrm{Na}_{2} \mathrm{WO}_{4} \cdot 2 \mathrm{H}_{2} \mathrm{O}, 10 \mathrm{mg} \mathrm{Fe}\left(\mathrm{NH}_{4}\right)_{2}\left(\mathrm{SO}_{4}\right)_{2} \cdot 6 \mathrm{H}_{2} \mathrm{O}$, $20 \mathrm{mg} \mathrm{FeSO} \mathrm{S}_{4} .5 \mathrm{H}_{2} \mathrm{O}, 1 \mathrm{mg}$ resazurin, $10 \mathrm{ml}$ modified trace mineral solution (described below), $10 \mathrm{ml}$ vitamin solution (Balch et al., 1979), $3 \%(\mathrm{w} / \mathrm{v})$ elemental sulfur, $20 \mathrm{~g}$ $\mathrm{NaHCO}_{3}$ and $0.5 \mathrm{~g} \mathrm{Na} 2 \mathrm{~S} .9 \mathrm{H}_{2} \mathrm{O}$ per litre of distilled, deionized water (DDW). Modified trace mineral solution contained $0.15 \mathrm{~g}$ nitrilotriacetic acid, $0.5 \mathrm{~g} \mathrm{MnSO}_{4} \cdot 2 \mathrm{H}_{2} \mathrm{O}$, $0.5 \mathrm{~g} \quad \mathrm{CoSO}_{4} .7 \mathrm{H}_{2} \mathrm{O}, \quad 0.18 \mathrm{~g} \quad \mathrm{ZnSO}_{4} .7 \mathrm{H}_{2} \mathrm{O}, \quad 0.01 \mathrm{~g}$ $\mathrm{CuSO}_{4} .5 \mathrm{H}_{2} \mathrm{O}, 0.02 \mathrm{~g} \mathrm{KAl}\left(\mathrm{SO}_{4}\right)_{2} .12 \mathrm{H}_{2} \mathrm{O}, 0.01 \mathrm{~g} \mathrm{H}_{3} \mathrm{BO}_{3}$, $0.001 \mathrm{~g} \mathrm{Na}_{2} \mathrm{MoO}_{4} \cdot 2 \mathrm{H}_{2} \mathrm{O}, 0 \cdot 01 \mathrm{~g} \mathrm{SrCl}_{2} .6 \mathrm{H}_{2} \mathrm{O}, 0.01 \mathrm{~g} \mathrm{NaBr}$ and $0.01 \mathrm{~g} \mathrm{KI}(1 \mathrm{DDW})^{-1}$. To prepare the medium, materials other than the vitamin solution, elemental sulfur, $\mathrm{NaHCO}_{3}$ and $\mathrm{Na}_{2} \mathrm{~S} .9 \mathrm{H}_{2} \mathrm{O}$ were dissolved and the $\mathrm{pH}$ of the medium was adjusted to around $5 \cdot 5$ with $\mathrm{HCl}$ 

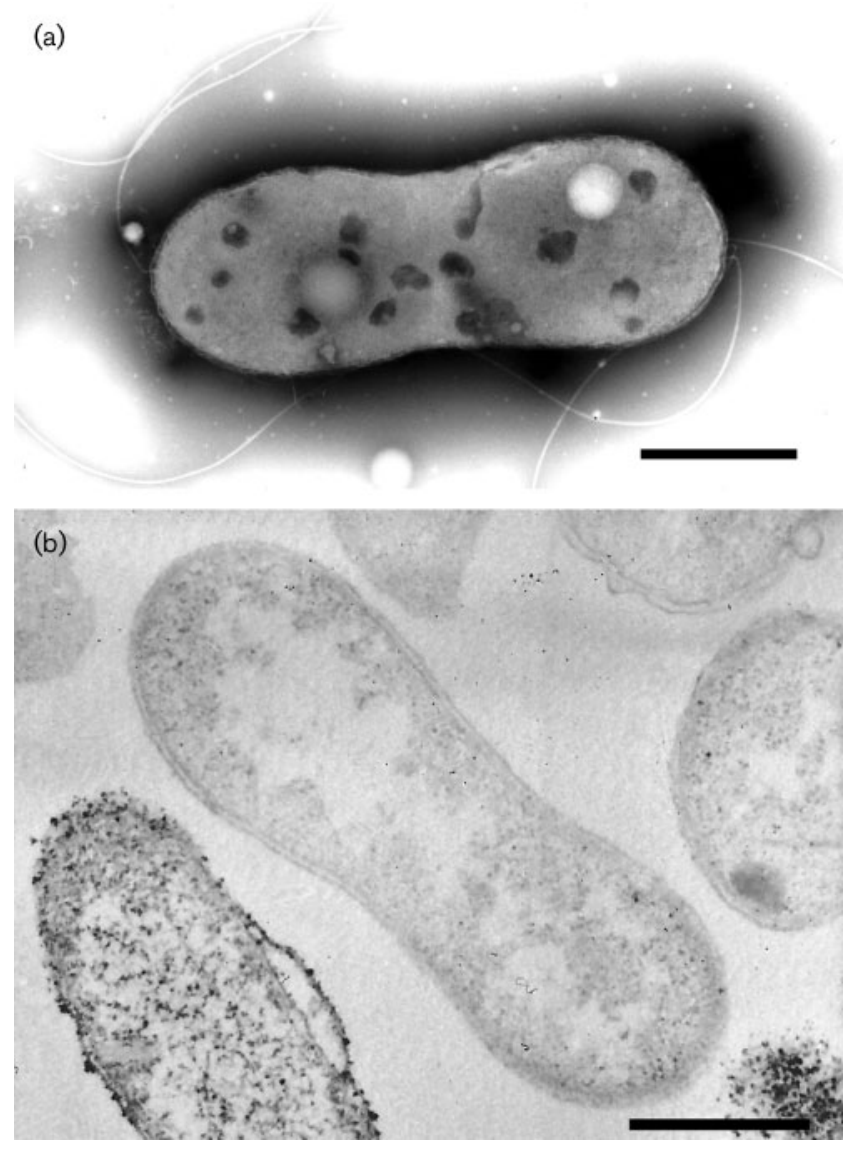

Fig. 1. Electron micrographs of (a) a negatively stained cell and (b) a thin section of a cell in the mid-exponential phase of growth. Bars, $0.5 \mu \mathrm{m}$.

before autoclaving. After autoclaving under air atmosphere, a concentrated solution of vitamins, $\mathrm{NaHCO}_{3}$, elemental sulfur and $\mathrm{Na}_{2} \mathrm{~S}$ (pH adjusted to $7 \cdot 0$ ) was added to the medium under gas purging of $80 \% \mathrm{H}_{2}$ and $20 \% \mathrm{CO}_{2}$; the $\mathrm{pH}$ was readjusted to $5 \cdot 5$ with $\mathrm{HCl}$ unless otherwise noted. These solutions were sterilized separately by autoclaving except for the vitamins and elemental sulfur, which were filter- or steam-sterilized (three times at $95^{\circ} \mathrm{C}$ for $3 \mathrm{~h}$ ), respectively. Medium was dispensed at $20 \%$ of the total volume of the bottle (Schott Glaswerke) or tube (Iwaki Glass) and containers were sealed tightly with a butyl rubber stopper under a gas phase that consisted of $80 \% \mathrm{H}_{2}$ and $20 \% \mathrm{CO}_{2}$ at $400 \mathrm{kPa}$. All experiments described below were conducted in duplicate.

The effects of temperature, $\mathrm{pH}$ and $\mathrm{NaCl}$ concentration in MJAIS medium on growth were tested (Fig. 2). With MJAIS medium, strain $17 \mathrm{~S}^{\mathrm{T}}$ grew at about $45-80{ }^{\circ} \mathrm{C}$, showing optimal growth at $70-75^{\circ} \mathrm{C}$, and generation time at $75^{\circ} \mathrm{C}, \mathrm{pH} 5 \cdot 5$, was about $80 \mathrm{~min}$ (see Supplementary Figure in IJSEM Online). No growth was observed at 35 or $85^{\circ} \mathrm{C}$. To determine the effect of $\mathrm{pH}$ on growth, the $\mathrm{pH}$ of MJAIS medium was adjusted to various levels with $10 \mathrm{mM}$ acetate/acetic acid buffer ( $\mathrm{pH} 4-5)$, MES ( $\mathrm{pH}$ 5-6), PIPES ( $\mathrm{pH} 6-7)$, HEPES $(\mathrm{pH} \mathrm{7-7 \cdot 5)}$ or Tris $(\mathrm{pH} 8-9 \cdot 5)$ at room temperature. Growth of strain $17 \mathrm{~S}^{\mathrm{T}}$ at $70^{\circ} \mathrm{C}$ occurred at $\mathrm{pH} 5 \cdot 0-7 \cdot 0$, with optimum growth at about $\mathrm{pH} 5 \cdot 4$ (see Supplementary Figure in IJSEM Online). The $\mathrm{pH}$ was found to be stable during the cultivation period. The effect of $\mathrm{NaCl}$ concentration in MJAIS medium on growth was determined with MJAIS medium that contained varying concentrations of $\mathrm{NaCl}$. Isolate $17 \mathrm{~S}^{\mathrm{T}}$ grew at concentrations of 8-56 $\mathrm{g} \mathrm{NaCl} \mathrm{l}^{-1}$, with optimum growth at $32 \mathrm{~g} \mathrm{NaCl} \mathrm{l}^{-1}$ at $70{ }^{\circ} \mathrm{C}$ and $\mathrm{pH} 5.5$ (see Supplementary Figure in IJSEM Online). As compared to T. ruber ED11/3LLK ${ }^{\mathrm{T}}$ (Huber et al., 2002) and D. thermolithotrophum $\mathrm{BSA}^{\mathrm{T}}$ (L'Haridon et al., 1998), strain $17 \mathrm{~S}^{\mathrm{T}}$ had a lower optimal growth $\mathrm{pH}$ (Table 1).

Oxygen sensitivity of strain $17 S^{\mathrm{T}}$ was tested with MJAIS medium under a gas phase that was replaced with a mixture of $80 \% \mathrm{H}_{2}, 19 \% \mathrm{CO}_{2}$ and $1 \% \mathrm{O}_{2}(400 \mathrm{kPa})$ or a mixture of $80 \% \mathrm{H}_{2}, 19 \cdot 9 \% \mathrm{CO}_{2}$ and $0 \cdot 1 \% \mathrm{O}_{2}(400 \mathrm{kPa})$. Strain $17 \mathrm{~S}^{\mathrm{T}}$ only grew under strictly anaerobic culture conditions and was extremely sensitive to oxygen.

Heterotrophic growth was determined in MJAIS medium without $\mathrm{NaHCO}_{3}$ under a gas phase of $100 \% \mathrm{H}_{2}(400 \mathrm{kPa})$ that contained potential carbon sources: $0.2 \%(\mathrm{w} / \mathrm{v})$ yeast extract, $0 \cdot 2 \%(\mathrm{w} / \mathrm{v})$ peptone, $0 \cdot 2 \%(\mathrm{w} / \mathrm{v})$ tryptone, $0 \cdot 2 \%$ $(\mathrm{w} / \mathrm{v})$ Casamino acids, $5 \mathrm{mM}$ formate, $5 \mathrm{mM}$ acetate, $5 \mathrm{mM}$ glycerol, $0.025 \%(\mathrm{v} / \mathrm{v})$ methanol, $0.05 \%(\mathrm{v} / \mathrm{v})$ ethanol, $0.1 \%(\mathrm{v} / \mathrm{v})$ 2-propanol, $5 \mathrm{mM}$ citrate, $5 \mathrm{mM}$ tartrate, $5 \mathrm{mM}$ fumarate, $5 \mathrm{mM}$ maleate, $5 \mathrm{mM}$ succinate, $5 \mathrm{mM}$ propionate, $5 \mathrm{mM}$ malate, $5 \mathrm{mM}$ lactate, $5 \mathrm{mM}$ oxalate, $5 \mathrm{mM}$ thioglycolate, $5 \mathrm{mM}$ pyruvate, $5 \mathrm{mM}$ of each of 20 amino acids, $0 \cdot 1 \%(\mathrm{w} / \mathrm{v})$ glucose, $0 \cdot 1 \%(\mathrm{w} / \mathrm{v})$ galactose, $0 \cdot 1 \%(\mathrm{w} / \mathrm{v})$ sucrose, $0 \cdot 1 \%(\mathrm{w} / \mathrm{v})$ fructose, $0 \cdot 1 \%(\mathrm{w} / \mathrm{v})$ lactose, $0 \cdot 1 \%(\mathrm{w} / \mathrm{v})$ maltose, $0 \cdot 1 \%(\mathrm{w} / \mathrm{v})$ arabinose, $0 \cdot 1 \%$ $(\mathrm{w} / \mathrm{v})$ trehalose or $0 \cdot 1 \%(\mathrm{w} / \mathrm{v})$ starch. Strain $17 \mathrm{~S}^{\mathrm{T}}$ was not able to grow with any heterotrophic substrates by using $\mathrm{H}_{2}$ as energy source and elemental sulfur as electron acceptor. Utilization of these organic compounds as an alternative energy source to $\mathrm{H}_{2}$ was also examined in MJAIS medium under a gas phase of $80 \% \mathrm{~N}_{2}$ and $20 \%$ $\mathrm{CO}_{2}(400 \mathrm{kPa})$. None of the organic compounds sustained growth of strain $17 S^{\mathrm{T}}$. In an attempt to determine potential electron donors and acceptors other than a combination of $\mathrm{H}_{2}$ and elemental sulfur for autotrophic growth, a combination of thiosulfate $(20 \mathrm{mM})$, sulfite (5 and $20 \mathrm{mM}$ ) or ferrous iron $(20 \mathrm{mM})$ and nitrate $(10 \mathrm{mM})$ and a combination of $\mathrm{H}_{2}$ and sulfite (2 and $10 \mathrm{mM}$ ), thiosulfate $(10 \mathrm{mM})$, tetrathionate $(10 \mathrm{mM})$, nitrate $(10 \mathrm{mM})$, nitrite ( 1 and $5 \mathrm{mM})$, ferric citrate $(20 \mathrm{mM})$, ferrihydrite $(20 \mathrm{mM})$, selenate $(5 \mathrm{mM})$, arsenate $(5 \mathrm{mM})$ or fumarate $(10 \mathrm{mM})$ were tested. Anaerobic cultivation procedure in the absence of $\mathrm{Na}_{2} \mathrm{~S} .9 \mathrm{H}_{2} \mathrm{O}$ was described previously (Takai et al., 2003a). None of the combinations other than $\mathrm{H}_{2}$ and elemental sulfur supported growth of strain $17 \mathrm{~S}^{\mathrm{T}}$. Nutrients potentially required for growth, such as selenite, tungstate and vitamins, were examined with MJAIS medium in the 
Table 1. Comparison of properties among Balnearium lithotrophicum strain $17 S^{\top}$, Desulfurobacterium thermolithotrophum strain $\mathrm{BSA}^{\mathrm{T}}$ and Thermovibrio ruber strain ED11/3LLK ${ }^{\top}$

Taxa: 1, B. lithotrophicum $17 \mathrm{~S}^{\mathrm{T}}$ (data from this study); 2, D. thermolithotrophum $\mathrm{BSA}^{\mathrm{T}}$ [data from L'Haridon et al. (1998)]; 3, T. ruber ED11/3LLK ${ }^{\mathrm{T}}$ [data from Huber et al. (2002)]. All taxa can utilize $\mathrm{H}_{2}$, but not organic compounds, as electron donors and can utilize elemental sulfur as an electron acceptor. +, Positive; -, negative; ND, not determined.

\begin{tabular}{|c|c|c|c|}
\hline Characteristic & 1 & 2 & 3 \\
\hline Cell shape & $\begin{array}{l}\text { Short rod, narrow } \\
\text { in the middle }\end{array}$ & Short rod & Curved rod \\
\hline Motility & Not observed & High & High \\
\hline \multicolumn{4}{|l|}{ Temperature for growth $\left({ }^{\circ} \mathrm{C}\right)$ : } \\
\hline Range & $45-80$ & $40-75$ & $50-80$ \\
\hline Optimum & $70-75$ & 70 & $70-75$ \\
\hline Doubling time under optimal conditions (min) & 80 & 135 & Approx. 100 \\
\hline \multicolumn{4}{|l|}{ pH range for growth: } \\
\hline Range & $5 \cdot 0-7 \cdot 0$ & $4 \cdot 4-8 \cdot 0$ & $5 \cdot 0-6 \cdot 5$ \\
\hline Optimum & $5 \cdot 4$ & Approx. $6 \cdot 25$ & 6 \\
\hline \multicolumn{4}{|l|}{$\mathrm{NaCl}$ concentration for growth (\%): } \\
\hline Range & $0 \cdot 8-5 \cdot 6$ & $1 \cdot 5-7 \cdot 0$ (sea salts) & $2 \cdot 0-4 \cdot 7$ \\
\hline Optimum & $3 \cdot 2$ & $3 \cdot 5$ (sea salts) & 3 \\
\hline \multicolumn{4}{|l|}{ Electron acceptor: } \\
\hline Thiosulfate & - & + & - \\
\hline Sulfite & - & + & - \\
\hline Nitrate & - & - & + \\
\hline \multicolumn{4}{|l|}{ Nitrogen source: } \\
\hline Ammonium & + & - & ND \\
\hline Nitrate & Inhibitory & + & + \\
\hline $\mathrm{G}+\mathrm{C}$ content of genomic DNA (mol\%) & $34 \cdot 6$ & 35 & 47 \\
\hline
\end{tabular}

absence of the material to test; nitrogen source for growth $\left(\mathrm{NaNO}_{2}, \mathrm{~N}_{2}\right.$ or $\left.\mathrm{NaNO}_{3}\right)$ was also examined with MJAIS medium instead of $\mathrm{NH}_{4} \mathrm{Cl}$. Isolate $17 \mathrm{~S}^{\mathrm{T}}$ utilized ammonium as a nitrogen source but could not utilize nitrate, molecular nitrogen or nitrite. Addition of nitrate (at least $1 \mathrm{mM}$ ) or

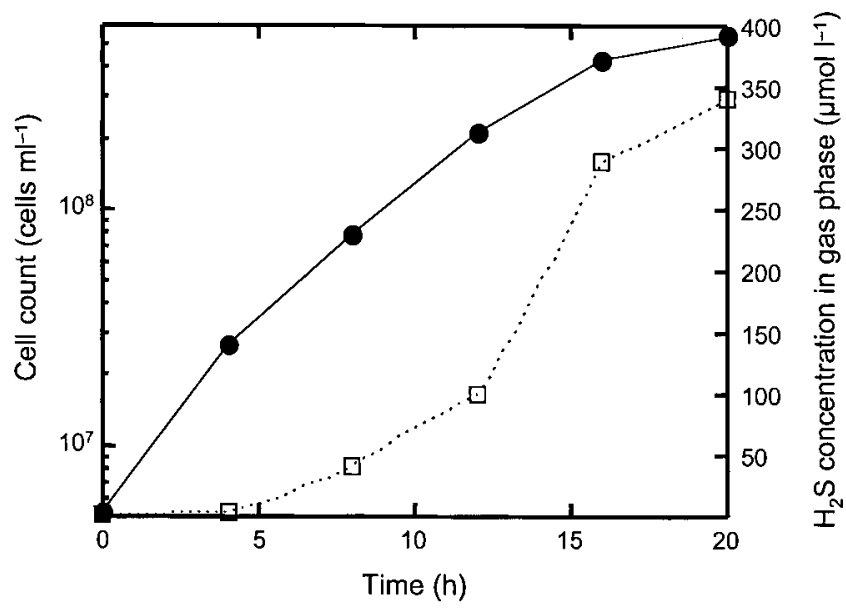

Fig. 2. Time-course of reduction of elemental sulfur ( $\square$ ) and concomitant bacterial growth (0) of Balnearium lithotrophicum strain $17 \mathrm{~S}^{\top}$. nitrite (at least $0.005 \mathrm{mM}$ ) into MJAIS medium that contained $0 \cdot 125 \%(\mathrm{w} / \mathrm{v}) \quad \mathrm{NH}_{4} \mathrm{Cl}$ completely inhibited growth. Selenium, tungsten and vitamins were not required for growth. However, when the concentration of $\mathrm{CaCl}_{2}$ in MJAIS medium was reduced from 0.08 to $0.01 \%$ $(\mathrm{w} / \mathrm{v})$, maximum cell yield of strain $17 \mathrm{~S}^{\mathrm{T}}$ was decreased to $8 \cdot 0 \times 10^{7}$ cells ml ${ }^{-1}$ (usually $5 \cdot 0-6 \cdot 0 \times 10^{8}$ cells ml $^{-1}$ under optimal conditions in MJAIS medium). These results indicated that strain $17 \mathrm{~S}^{\mathrm{T}}$ was a chemolithoautotroph that utilized hydrogen as sole electron donor, elemental sulfur as sole electron acceptor and carbon dioxide as sole carbon source for growth. Strain $17 \mathrm{~S}^{\mathrm{T}}$ resembled T. ruber ED11/3LLK ${ }^{\mathrm{T}}$ (Huber et al., 2002) and D. thermolithotrophum $\mathrm{BSA}^{\mathrm{T}}$ (L'Haridon et al., 1998) in the utilization of molecular hydrogen as sole electron donor, whereas it could not use nitrate as an alternative electron acceptor (as T. ruber strain ED11/3LLK ${ }^{\mathrm{T}}$ ) or thiosulfate and sulfite (as D. thermolithotrophum strain $\mathrm{BSA}^{\mathrm{T}}$ ) (Table 1). Stimulation of growth by complex organic substrates, as observed in T. ruber ED11/3LLK ${ }^{\mathrm{T}}$ (Huber et al., 2002), was negative in strain $17 \mathrm{~S}^{\mathrm{T}}$ and $D$. thermolithotrophum $\mathrm{BSA}^{\mathrm{T}}$ (L'Haridon et al., 1998). Furthermore, inability to use nitrate as a nitrogen source and the inhibition of growth of $17 \mathrm{~S}^{\mathrm{T}}$ by nitrate were distinct from the characteristics of $T$. ruber ED11/3LLK ${ }^{\mathrm{T}}$ (Huber et al., 2002) and D. thermolithotrophum $\mathrm{BSA}^{\mathrm{T}}$ (L'Haridon et al., 1998). 
Time-courses of reduction of elemental sulfur and concomitant bacterial growth of strain $17 \mathrm{~S}^{\mathrm{T}}$ were examined with MJAIS medium under a gas phase of $80 \% \mathrm{H}_{2}+20 \%$ $\mathrm{CO}_{2}(400 \mathrm{kPa})$ (Fig. 2). Concentration of hydrogen sulfide in the gas phase during growth was measured by using a Micro GC CP2002 gas chromatograph (GL Sciences). Although consumption of molecular hydrogen and elemental sulfur was not measured because growth of strain $17 S^{T}$ required too much hydrogen and sulfur in the medium, the concentration of hydrogen sulfide increased during growth of strain $17 \mathrm{~S}^{\mathrm{T}}$ (Fig. 2). As control medium without inoculum of the bacterial culture did not demonstrate reduction of elemental sulfur, bacterial reduction of elemental sulfur occurred during growth. Strain $17 \mathrm{~S}^{\mathrm{T}}$ was found to be a respiratory hydrogen-oxidizing, sulfurreducing chemolithoautotroph.

Sensitivity of strain $17 S^{\mathrm{T}}$ to antibiotics such as chloramphenicol (50 and $100 \mu \mathrm{g} \mathrm{ml}^{-1}$ ), streptomycin (50 and $\left.100 \mu \mathrm{g} \mathrm{ml}^{-1}\right)$, kanamycin $\left(50\right.$ and $100 \mu \mathrm{g} \mathrm{ml}^{-1}$ ), ampicillin $\left(50\right.$ and $100 \mu \mathrm{g} \mathrm{ml}^{-1}$ ) and rifampicin $\left(50\right.$ and $100 \mu \mathrm{g} \mathrm{ml}^{-1}$ ) was tested at $70^{\circ} \mathrm{C}$. Strain $17 \mathrm{~S}^{\mathrm{T}}$ was sensitive to chloramphenicol $\left(50 \mu \mathrm{g} \mathrm{ml}^{-1}\right)$, streptomycin $\left(100 \mu \mathrm{g} \mathrm{ml}^{-1}\right)$ and rifampicin $\left(50 \mu \mathrm{g} \mathrm{ml}^{-1}\right)$, but showed resistance to streptomycin $\left(50 \mu \mathrm{g} \mathrm{ml}^{-1}\right)$ and kanamycin (up to $100 \mu \mathrm{g} \mathrm{ml}^{-1}$ ). Antibiotic susceptibility was similar among strain $17 \mathrm{~S}^{\mathrm{T}}$, T. ruber ED11/3LLK ${ }^{\mathrm{T}}$ (Huber et al., 2002) and D. thermolithotrophum $\mathrm{BSA}^{\mathrm{T}}$ (L'Haridon et al., 1998).

\section{Molecular properties}

Cellular fatty acid composition was analysed by using cells grown in MJAIS medium at $70{ }^{\circ} \mathrm{C}$ in the late-exponential growth phase. Lyophilized cells $(50 \mathrm{mg})$ were placed in a Teflon-lined, screw-capped tube that contained $3 \mathrm{ml}$ anhydrous methanolic $\mathrm{HCl}$ and heated at $100{ }^{\circ} \mathrm{C}$ for $3 \mathrm{~h}$. The resulting fatty acid methyl esters (FAMEs) were extracted twice with $\mathrm{n}$-hexane and concentrated under a stream of nitrogen gas. FAMEs were analysed by using a model GC-380 gas-liquid chromatograph (GL Sciences) equipped with a gas-liquid chromatograph mass spectrometer (GCMS-QP5050; Shimadzu). The major cellular fatty acids of strain $17 \mathrm{~S}^{\mathrm{T}}$ were $\mathrm{C}_{16: 0}(10 \cdot 9 \%), \mathrm{C}_{18: 0}(33.5 \%)$ and $\mathrm{C}_{18: 1}(55 \cdot 6 \%)$, which were quite similar to those of D. thermolithotrophum $\mathrm{BSA}^{\mathrm{T}}$ (L'Haridon et al., 1998), but different from those of members of other genera in the Aquificae (Takai et al., 2001b, 2003b; Nakagawa et al., 2003). Genomic DNA of strain $17 \mathrm{~S}^{\mathrm{T}}$ was prepared as described by Marmur \& Doty (1962). The G $+C$ content of DNA was determined by direct analysis of deoxyribonucleotides by HPLC (Tamaoka \& Komagata, 1984). The G + C content of the genomic DNA of strain $17 \mathrm{~S}^{\mathrm{T}}$ was $34 \cdot 6 \mathrm{~mol} \%$, which was similar to that of $D$. thermolithotrophum $\mathrm{BSA}^{\mathrm{T}}$ (35 mol\%; L'Haridon et al., 1998) and lower than that of T. ruber ED11/3LLK ${ }^{\mathrm{T}}$ (47 mol\%; Huber et al., 2002) (Table 1).

The 16S rRNA gene (rDNA) was amplified by PCR, using primers Bac 27F and 1492R (Lane, 1985; DeLong, 1992), as described previously (Takai et al., 2001b). The nearly complete $16 \mathrm{~S}$ rDNA sequence (1481 bp) from strain $17 \mathrm{~S}^{\mathrm{T}}$ was sequenced directly on both strands by using the ddNTP chain-termination method with a model 3100 DNA sequencer (PerkinElmer Applied Biosystems). The rDNA sequence was analysed by using the gapped-BLAST search algorithm (Altschul et al., 1997; Benson et al., 1998) and was found to be related to the sequences of D. thermolithotrophum $\mathrm{BSA}^{\mathrm{T}}$ (L'Haridon et al., 1998) and T. ruber ED11/3LLK ${ }^{\mathrm{T}}$ (Huber et al., 2002) $(93 \cdot 1$ and $94 \cdot 4 \%$ similarity, respectively). The nearly complete sequence was realigned manually with $16 \mathrm{~S}$ rDNA data from the Ribosomal Data Project II (RDP-II) (Maidak et al., 2000), based on alignments determined by using the Sequence Aligner program of RDP-II. Phylogenetic analyses were restricted to nucleotide positions that could be aligned unambiguously. Evolutionary distance matrix analysis (using the Kimura two-parameter model, the least-squares distance method and a transition/transversion ratio of $2 \cdot 0$ ) and neighbour-joining analysis were performed by using the PHYLIP package (version 3.5; obtained from J. Felsenstein, University of Washington, Seattle, WA, USA) (Fig. 3). Bootstrap analysis was performed to provide confidence estimates for phylogenetic tree topologies. The phylogenetic tree indicated that strain $17 \mathrm{~S}^{\mathrm{T}}$ represented a separate lineage, prior to the divergence of $D$. thermolithotrophum $\mathrm{BSA}^{\mathrm{T}}$ (L'Haridon et al., 1998) from T. ruber ED11/3LLK ${ }^{\mathrm{T}}$ (Huber et al., 2002) (Fig. 3).

\section{Comparison with related genera}

Phylogenetic analysis indicates that strain $17 \mathrm{~S}^{\mathrm{T}}$ is phylogenetically associated with $D$. thermolithotrophum $\mathrm{BSA}^{\mathrm{T}}$ and T. ruber ED11/3LLK ${ }^{\mathrm{T}}$, which were isolated from a deepsea hydrothermal vent chimney structure at the Snake Pit field in the MAR (L'Haridon et al., 1998) and coastal marine hydrothermal water and sediments in Papua New Guinea (Huber et al., 2002), respectively. 16S rDNA sequence similarity levels between strain $17 \mathrm{~S}^{\mathrm{T}}$ and either $D$. thermolithotrophum $\mathrm{BSA}^{\mathrm{T}}(93 \cdot 1 \%)$ or T. ruber strain ED11/3LLK ${ }^{\mathrm{T}}$ $(94 \cdot 4 \%)$ are similar to the value that differentiates the genera Desulfurobacterium and Thermovibrio (93.5\%). The $16 \mathrm{~S}$ rDNA sequence similarity level is within the common index of $16 \mathrm{~S}$ rDNA sequence similarity for genus-level differentiation (90-96\%) (Gillis et al., 2001). In addition, phylogenetic characterization shows that strain $17 S^{T}$ is a separate phylotype that diverged prior to differentiation between the genera Desulfurobacterium and Thermovibrio. These results suggest that strain $17 S^{\mathrm{T}}$ can be classified genetically as a novel genus of the phylum Aquificae. Morphological and physiological properties of strain $17 \mathrm{~S}^{\mathrm{T}}$ reinforce its genus-level differentiation from Desulfurobacterium and Thermovibrio (Table 1). Cells of both D. thermolithotrophum $\mathrm{BSA}^{\mathrm{T}}$ and T. ruber ED11/3LLK ${ }^{\mathrm{T}}$ are characterized as highly motile, straight to curved rods with polar flagella (L'Haridon et al., 1998; Huber et al., 2002); nevertheless, most cells of strain $17 \mathrm{~S}^{\mathrm{T}}$ in the exponentialgrowth phase appear to be non-motile and narrow in the middle (Table 1 ). Strain $17 \mathrm{~S}^{\mathrm{T}}$ grows optimally at a lower 


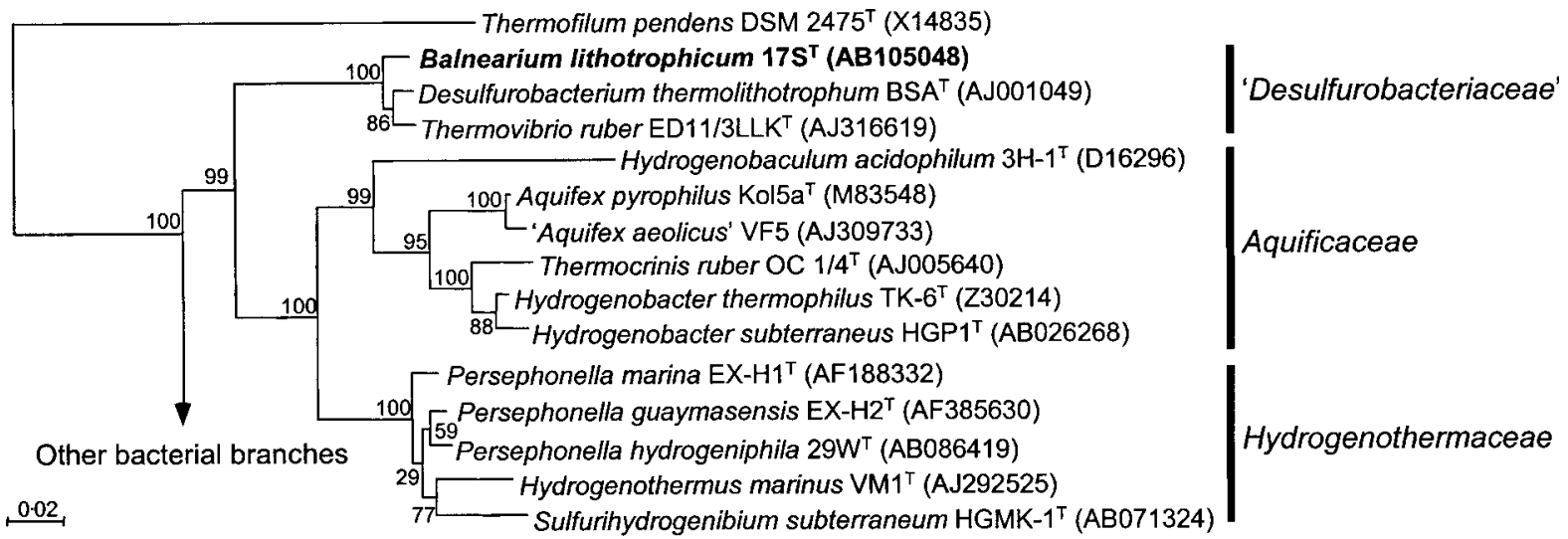

Fig. 3. Phylogenetic tree of representative bacterial strains potentially related to Balnearium lithotrophicum $17 \mathrm{~S}^{\top}$, inferred from 16S rDNA sequences by using the neighbour-joining method on 1121 homologous sequence positions for each organism. Numbers at nodes represent bootstrap values (100 replicates). Bar, 2 substitutions per 100 nucleotides.

$\mathrm{pH}(5 \cdot 4)$ than D. thermolithotrophum $\mathrm{BSA}^{\mathrm{T}}$ or T. ruber ED11/3LLK ${ }^{\mathrm{T}}$ (Table 1). Hydrogen-dependent energy metabolism, associated with strict chemolithoautotrophy, is common to strain $17 \mathrm{~S}^{\mathrm{T}}$, D. thermolithotrophum $\mathrm{BSA}^{\mathrm{T}}$ and T. ruber ED11/3LLK ${ }^{\mathrm{T}}$, whilst strain $17 \mathrm{~S}^{\mathrm{T}}$ can utilize only elemental sulfur as an electron acceptor (Table 1). In addition, inability to utilize nitrate as a nitrogen source and the inhibitory effect of nitrate on growth were quite different from the preference of nitrate as electron acceptor and nitrogen source in T. ruber ED11/3LLK ${ }^{\mathrm{T}}$ and as the primary nitrogen source in D. thermolithotrophum $\mathrm{BSA}^{\mathrm{T}}$ (Table 1). On the basis of these physiological and molecular properties of strain $17 \mathrm{~S}^{\mathrm{T}}$, we propose a novel genus, Balnearium gen. nov. The type species is Balnearium lithotrophicum sp. nov., with the type strain $17 \mathrm{~S}^{\mathrm{T}}$ (= JCM $11970^{\mathrm{T}}=$ ATCC BAA- $736^{\mathrm{T}}$ ).

Strictly anaerobic, hydrogen-oxidizing, thermophilic chemolithoautotrophs are likely to be important as primary producers in microbial ecosystems that occur in endolithic habitats of deep-sea hydrothermal environments, and even of the subvent biosphere (Takai et al., 2001a). Metabolic requirements $\left(\mathrm{H}_{2}, \mathrm{CO}_{2}, \mathrm{~N}_{2}\right.$ and $\mathrm{H}_{2} \mathrm{~S}$ as energy, carbon, nitrogen and sulfur sources, respectively) of most thermophilic methanogens (members of the orders Methanopyrales and Methanococcales) obtained from a variety of deepsea hydrothermal systems are all provided directly by the superheated hydrothermal emission (Von Damm, 1995; Shanks, 2001). Other than thermophilic methanogens, sulfur-reducing, hydrogen-oxidizing thermophiles may serve as potential primary producers that are completely dependent on energy and substance inputs from the hydrothermal emission. On this account, deep-sea hydrothermal vent chemolithoautotrophs related to the genera Ignicoccus (Huber et al., 2000), and Desulfurobacterium (L'Haridon et al., 1998) that have so far been isolated from deep-sea hydrothermal environments are expected to be potential candidates. Molecular phylogenetic surveys have suggested the predominant occurrence of Desulfurobacterium and other phylogenetically related Aquificae in the bacterial population, and members of the order Ignicoccales in the archaeal rDNA population, in deep-sea hydrothermal vent chimney structures at the Snake Pit field in the MAR (Harmsen et al., 1997) and at the PACMANUS site in the Manus Basin (Takai et al., 2001a), respectively. From the Suiyo Seamount deep-sea hydrothermal system, detection of thermophilic methanogens by using both culturedependent and -independent analyses has as yet been unsuccessful (Takai \& Horikoshi, 1999; Nakagawa et al., 2003; Sako et al., 2003; Takai et al., 2003a). Balnearium lithotrophicum $17 \mathrm{~S}^{\mathrm{T}}$ represents the first strictly anaerobic, sulfur-reducing, hydrogen-oxidizing, chemolithoautotrophic thermophile to be isolated from the Suiyo Seamount field. It seems likely, therefore, that this bacterium and its relatives play an important role in energy and carbon fluxes of the microbial ecosystem derived from the hydrothermal activity in the field.

\section{Description of Balnearium gen. nov.}

Balnearium (Bal.ne.a'ri.um. N.L. neut. subst. from L. neut. adj. balnearium pertaining to a bath).

Short rods with polar flagella. Gram-negative. Strictly anaerobic and thermophilic. Chemolithoautotrophic. Able to utilize molecular hydrogen and elemental sulfur as electron donor and electron acceptor, respectively. $\mathrm{NaCl}$ is absolutely required for growth. $\mathrm{G}+\mathrm{C}$ content of genomic DNA is about $35 \mathrm{~mol} \%$. Major cellular fatty acids are $\mathrm{C}_{16: 0}$, $\mathrm{C}_{18: 0}$ and $\mathrm{C}_{18: 1}$. On the basis of $16 \mathrm{~S}$ rRNA gene sequence analysis, the genus Balnearium is related most closely to the genera Thermovibrio and Desulfurobacterium. Members of the genus Balnearium occur in marine hydrothermal systems. The type species is Balnearium lithotrophicum. 


\section{Description of Balnearium lithotrophicum sp. nov.}

Balnearium lithotrophicum (li.tho.tro'phi.cum. Gr. n. lithos stone; Gr. adj. trophikos nursing, tending or feeding; N.L. neut. adj. lithotrophicum referring to its lithotrophic metabolism).

Each cell is a short rod with several polar flagella at both ends, mostly narrow in the middle, with mean length of $2 \cdot 5-3 \cdot 5 \mu \mathrm{m}$ and width of approximately $0 \cdot 7-0 \cdot 9 \mu \mathrm{m}$. Cells are non-motile in laboratory cultures and occur singly. Gram-negative. Strictly anaerobic and sensitive to molecular oxygen. Temperature range for growth is $45-80{ }^{\circ} \mathrm{C}$ (optimum, $70-75^{\circ} \mathrm{C}$ ). $\mathrm{pH}$ range for growth is $5 \cdot 0-7 \cdot 0$ (optimum $\mathrm{pH}, 5 \cdot 4$ ). $\mathrm{NaCl}$, in the range $8-56 \mathrm{~g} \mathrm{l}^{-1}$, is an absolute growth requirement; optimum growth occurs at $32 \mathrm{~g} \mathrm{l}^{-1}$. Strictly chemolithoautotrophic growth occurs with molecular hydrogen as electron donor and with elemental sulfur as electron acceptor. Elemental sulfur is reduced to hydrogen sulfide during growth. Ammonium is required as nitrogen source. Vitamins, selenium and tungsten are not required for growth. Presence of nitrate and nitrite is inhibitory. Major cellular fatty acids are $\mathrm{C}_{16: 0}(10 \cdot 9 \%), \mathrm{C}_{18: 0}(33 \cdot 5 \%)$ and $\mathrm{C}_{18: 1}(55 \cdot 6 \%)$. DNA $\mathrm{G}+\mathrm{C}$ content is $34.6 \mathrm{~mol} \%$ (by HPLC). $16 \mathrm{~S} \mathrm{rDNA}$ sequence exhibits $93 \cdot 1$ and $94 \cdot 4 \%$ similarity to those of

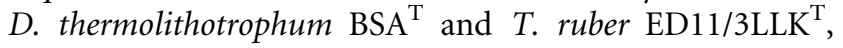
respectively.

The type strain is $17 \mathrm{~S}^{\mathrm{T}}$ ( = JCM $11970^{\mathrm{T}}=$ ATCC BAA-736 ${ }^{\mathrm{T}}$ ). The organism was isolated from a black smoker chimney at the Suiyo Seamount in the Izu-Bonin Arc, Japan.

\section{Acknowledgements}

We would like to thank Mr Katsuyuki Uematsu and Mr Takahiko Higasa for assistance in preparing electron micrographs. We are very grateful to the R/V Natsushima and the Shinkai 2000 operation teams for helping us to collect deep-sea hydrothermal vent samples.

\section{References}

Alain, K., Querellou, J., Lesongeur, F., Pignet, P., Crassous, P., Raguénès, G., Cueff, V. \& Cambon-Bonavita, M.-A. (2002). Caminibacter hydrogeniphilus gen. nov., sp. nov., a novel thermophilic, hydrogen-oxidizing bacterium isolated from an East Pacific Rise hydrothermal vent. Int J Syst Evol Microbiol 52, 1317-1323.

Altschul, S. F., Madden, T. L., Schäffer, A. A., Zhang, J., Zhang, Z., Miller, W. \& Lipman, D. J. (1997). Gapped BLAST and PSI-BLAST: a new generation of protein database search programs. Nucleic Acids Res 25, 3389-3402.

Balch, W. E., Fox, G. E., Magrum, L. J., Woese, C. R. \& Wolfe, R. S. (1979). Methanogens: reevaluation of a unique biological group. Microbiol Rev 43, 260-296.

Benson, D. A., Boguski, M. S., Lipman, D. J., Ostell, J. \& Ouellette, B. F. F. (1998). GenBank. Nucleic Acids Res 26, 1-7.

Blöchl, E., Rachel, R., Burggraf, S., Hafenbradl, D., Jannasch, H. W. \& Stetter, K. O. (1997). Pyrolobus fumarii, gen. and sp. nov., represents a novel group of archaea, extending the upper temperature limit for life to $113^{\circ} \mathrm{C}$. Extremophiles 1, 14-21.

Burggraf, S., Jannasch, H. W., Nicolaus, B. \& Stetter, K. O. (1990). Archaeoglobus profundus sp. nov., represents a new species within the sulfur-reducing Archaebacteria. Syst Appl Microbiol 13, 24-28.

DeLong, E. F. (1992). Archaea in coastal marine environments. Proc Natl Acad Sci U S A 89, 5685-5689.

Eder, W. \& Huber, R. (2002). New isolates and physiological properties of the Aquificales and description of Thermocrinis albus sp. nov. Extremophiles 6, 309-318.

Gillis, M., Vandamme, P., De Vos, P., Swings, J. \& Kersters, K. (2001). Polyphasic taxonomy. In Bergey's Manual of Systematic Bacteriology, 2nd edn, pp. 43-48. Edited by D. R. Boone, R. W. Castenholz \& G. M. Garrity. London: Springer.

Götz, D., Banta, A., Beveridge, T. J., Rushdi, A. I., Simoneit, B. R. T. \& Reysenbach, A.-L. (2002). Persephonella marina gen. nov., sp. nov. and Persephonella guaymasensis sp. nov., two novel, thermophilic, hydrogen-oxidizing microaerophiles from deep-sea hydrothermal vents. Int J Syst Evol Microbiol 52, 1349-1359.

Harmsen, H. J. M., Prieur, D. \& Jeanthon, C. (1997). Group-specific 16S rRNA-targeted oligonucleotide probes to identify thermophilic bacteria in marine hydrothermal vents. Appl Environ Microbiol 63, 4061-4068.

Huber, R., Kurr, M., Jannasch, H. W. \& Stetter, K. O. (1989). A novel group of abyssal methanogenic archaebacteria (Methanopyrus) growing at $110^{\circ} \mathrm{C}$. Nature 342, 833-834.

Huber, H., Jannasch, H., Rachel, R., Fuchs, T. \& Stetter, K. O. (1997). Archaeoglobus veneficus sp. nov., a novel facultative chemolithoautotrophic hyperthermophilic sulfite reducer, isolated from abyssal black smokers. Syst Appl Microbiol 20, 374-380.

Huber, H., Burggraf, S., Mayer, T., Wyschkony, I., Rachel, R. \& Stetter, K. O. (2000). Ignicoccus gen. nov., a novel genus of hyperthermophilic, chemolithoautotrophic Archaea, represented by two new species, Ignicoccus islandicus sp. nov. and Ignicoccus pacificus sp. nov. Int J Syst Evol Microbiol 50, 2093-2100.

Huber, H., Diller, S., Horn, C. \& Rachel, R. (2002). Thermovibrio ruber gen. nov., sp. nov., an extremely thermophilic, chemolithoautotrophic, nitrate-reducing bacterium that forms a deep branch within the phylum Aquificae. Int J Syst Evol Microbiol 52, 1859-1865. Jeanthon, C., L'Haridon, S., Reysenbach, A. L., Vernet, M., Messner, P., Sleytr, U. B. \& Prieur, D. (1998). Methanococcus infernus sp. nov., a novel hyperthermophilic lithotrophic methanogen isolated from a deep-sea hydrothermal vent. Int J Syst Bacteriol 48, 913-919.

Jeanthon, C., L'Haridon, S., Reysenbach, A.-L., Corre, E., Vernet, M., Messner, P., Sleytr, U. B. \& Prieur, D. (1999a). Methanococcus vulcanius sp. nov., a novel hyperthermophilic methanogen isolated from East Pacific Rise, and identification of Methanococcus sp. DSM $4213^{\mathrm{T}}$ as Methanococcus fervens sp. nov. Int J Syst Bacteriol 49, 583-589.

Jeanthon, C., L'Haridon, S., Pradel, N. \& Prieur, D. (1999b). Rapid identification of hyperthermophilic methanococci isolated from deep-sea hydrothermal vents. Int J Syst Bacteriol 49, 591-594.

Jones, W. J., Leigh, J. A., Mayer, F., Woese, C. R. \& Wolfe, R. S. (1983). Methanococcus jannaschii sp. nov., an extremely thermophilic methanogen from a submarine hydrothermal vent. Arch Microbiol 136, 254-261.

Jones, W. J., Stugard, C. E. \& Jannasch, H. W. (1989). Comparison of thermophilic methanogens from submarine hydrothermal vents. Arch Microbiol 151, 314-318.

Kashefi, K., Tor, J. M., Holmes, D. E., Gaw Van Praagh, C. V., Reysenbach, A.-L. \& Lovley, D. R. (2002). Geoglobus ahangari gen. 
nov., sp. nov., a novel hyperthermophilic archaeon capable of oxidizing organic acids and growing autotrophically on hydrogen with $\mathrm{Fe}(\mathrm{III})$ serving as the sole electron acceptor. Int J Syst Evol Microbiol 52, 719-728.

Kurr, M., Huber, R., König, H., Jannasch, H. W., Fricke, H., Trincone, A., Kristjansson, J. K. \& Stetter, K. O. (1991). Methanopyrus kandleri, gen. and sp. nov. represents a novel group of hyperthermophilic methanogens, growing at $110^{\circ} \mathrm{C}$. Arch Microbiol 156, 239-247.

Lane, D. J. (1985). 16S/23S sequencing. In Nucleic Acid Techniques in Bacterial Systematics, pp. 115-176. Edited by E. Stackbrandt \& M. Goodfellow. New York: Wiley.

L'Haridon, S., Cilia, V., Messner, P., Raguénès, G., Gambacorta, A., Sleytr, U. B., Prieur, D. \& Jeanthon, C. (1998). Desulfurobacterium thermolithotrophum gen. nov., sp. nov., a novel autotrophic, sulphurreducing bacterium isolated from a deep-sea hydrothermal vent. Int J Syst Bacteriol 48, 701-711.

Maidak, B. L., Cole, J. R., Lilburn, T. G. \& 9 other authors (2000). The RDP (Ribosomal Database Project) continues. Nucleic Acids Res 28, 173-174.

Marmur, J. \& Doty, P. (1962). Determination of the base composition of deoxyribonucleic acid from its thermal denaturation temperature. J Mol Biol 5, 109-118.

Miroshnichenko, M. L., Kostrikina, N. A., L'Haridon, S., Jeanthon, C., Hippe, H., Stackebrandt, E. \& Bonch-Osmolovskaya, E. A. (2002). Nautilia lithotrophica gen. nov., sp. nov., a thermophilic sulfurreducing $\varepsilon$-proteobacterium isolated from a deep-sea hydrothermal vent. Int J Syst Evol Microbiol 52, 1299-1304.

Nakagawa, S., Takai, K., Horikoshi, K. \& Sako, Y. (2003). Persephonella hydrogeniphila sp. nov., a novel thermophilic, hydrogenoxidizing bacterium from a deep-sea hydrothermal vent chimney. Int J Syst Evol Microbiol 53, 863-869.

Pley, U., Schipka, J., Gambacorta, A., Jannasch, H. W., Fricke, H., Rachel, R. \& Stetter, K. O. (1991). Pyrodictium abyssi sp. nov. represents a novel heterotrophic marine archaeal hyperthermophile growing at $110^{\circ}$ C. Syst Appl Microbiol 14, 245-253.

Reysenbach, A.-L., Banta, A. B., Boone, D. R., Cary, S. C. \& Luther, G. W. (2000). Microbial essentials at hydrothermal vents. Nature 404, 835.

Sako, Y., Takai, K., Ishida, Y., Uchida, A. \& Katayama, Y. (1996). Rhodothermus obamensis sp. nov., a modern lineage of extremely thermophilic marine bacteria. Int J Syst Bacteriol 46, 1099-1104.

Sako, Y., Nakagawa, S., Takai, K. \& Horikoshi, K. (2003). Marinithermus hydrothermalis gen. nov., sp. nov., a strictly aerobic, thermophilic bacterium from a deep-sea hydrothermal vent chimney. Int J Syst Evol Microbiol 53, 59-65.

Shanks, W. C., III (2001). Stable isotopes in seafloor hydrothermal systems: vent fluids, hydrothermal deposits, hydrothermal alteration, and microbial processes. In Stable Isotope Geochemistry (Reviews in Mineralogy and Geochemistry vol. 43), pp. 469-525. Edited by J. W. Valley \& D. R. Cole. Washington, DC: Mineralogy Society of America.
Takai, K. \& Horikoshi, K. (1999). Genetic diversity of archaea in deep-sea hydrothermal vent environments. Genetics 152, 1285-1297. Takai, K. \& Horikoshi, K. (2000). Thermosipho japonicus sp. nov., an extremely thermophilic bacterium isolated from a deep-sea hydrothermal vent in Japan. Extremophiles 4, 9-17.

Takai, K., Inoue, A. \& Horikoshi, K. (1999). Thermaerobacter marianensis gen. nov., sp. nov., an aerobic extremely thermophilic marine bacterium from the $11000 \mathrm{~m}$ deep Mariana Trench. Int J Syst Bacteriol 49, 619-628.

Takai, K., Komatsu, T., Inagaki, F. \& Horikoshi, K. (2001a). Distribution of archaea in a black smoker chimney structure. Appl Environ Microbiol 67, 3618-3629.

Takai, K., Komatsu, T. \& Horikoshi, K. (2001b). Hydrogenobacter subterraneus sp. nov., an extremely thermophilic, heterotrophic bacterium unable to grow on hydrogen gas, from deep subsurface geothermal water. Int J Syst Evol Microbiol 51, 1425-1435.

Takai, K., Inoue, A. \& Horikoshi, K. (2002). Methanothermococcus okinawensis sp. nov., a thermophilic, methane-producing archaeon isolated from a Western Pacific deep-sea hydrothermal vent system. Int J Syst Evol Microbiol 52, 1089-1095.

Takai, K., Kobayashi, H., Nealson, K. H. \& Horikoshi, K. (2003a). Deferribacter desulfuricans sp. nov., a novel sulfur-, nitrate- and arsenate-reducing thermophile isolated from a deep-sea hydrothermal vent. Int J Syst Evol Microbiol 53, 839-846.

Takai, K., Kobayashi, H., Nealson, K. H. \& Horikoshi, K. (2003b). Sulfurihydrogenibium subterraneum gen. nov., sp. nov., from a subsurface hot aquifer. Int J Syst Evol Microbiol 53, 823-827.

Takai, K., Inagaki, F., Nakagawa, S., Hirayama, H., Nunoura, T., Sako, Y., Nealson, K. H. \& Horikoshi, K. (2003c). Isolation and phylogenetic diversity of members of previously uncultivated $\varepsilon$-Proteobacteria in deep-sea hydrothermal fields. FEMS Microbiol Lett 218, 167-174.

Tamaoka, J. \& Komagata, K. (1984). Determination of DNA base composition by reverse-phase high-performance liquid chromatography. FEMS Microbiol Lett 25, 125-128.

Van Dover, C. L., Humphris, S. E., Fornari, D. \& 24 other authors (2001). Biogeography and ecological setting of Indian Ocean hydrothermal vents. Science 294, 818-823.

Von Damm, K. L. (1995). Controls on the chemistry and temporal variability of seafloor hydrothermal fluids. In Seafloor Hydrothermal Systems: Physical, Chemical, Biological, and Geological Interactions (Geophysical Monograph vol. 91), pp. 222-247. Edited by S. E. Humphris, R. A. Zierenberg, L. S. Mullineaux, R. E. Thomson \& D. E. Hayes. Washington, DC: American Geophysical Union.

Zhao, H., Wood, A. G., Widdel, F. \& Bryant, M. P. (1988). An extremely thermophilic Methanococcus from a deep sea hydrothermal vent and its plasmid. Arch Microbiol 150, 178-183.

Zillig, W., Holz, I., Janekovic, D. \& 7 other authors (1990). Hyperthermus butylicus, a hyperthermophilic sulfur-reducing archaebacterium that ferments peptides. J Bacteriol 172, 3959-3965. 